\title{
The hyporheic zone and its functions: revision and research status in Neotropical regions
}

\author{
Mugnai, R. ${ }^{a *}$, Messana, $G .^{b}$ and Di Lorenzo, $T .^{b}$ \\ ${ }^{a}$ Laboratório de Aracnologia, Departamento de Invertebrados, Museu Nacional, Universidade Federal do Rio de \\ Janeiro - UFRJ, Quinta da Boa Vista, s/n, São Cristóvão, CEP 20940-040, Rio de Janeiro, RJ, Brazil \\ ${ }^{\mathrm{b}}$ Istituto per lo Studio degli Ecosistemi, Consiglio Nazionale delle Ricerche, Via Madonna del Piano, \\ 10, 50019, Sesto Fiorentino, Italy \\ *e-mail: mugnai.riccardo@gmail.com
}

Received: August 30, 2013 - Accepted: April 28, 2014 - Distributed: August 31, 2015

\begin{abstract}
The hyporheic zone (HZ), as the connecting ecotone between surface- and groundwater, is functionally part of both fluvial and groundwater ecosystems. Its hydrological, chemical, biological and metabolic features are specific of this zone, not belonging truly neither to surface- nor to groundwater. Exchanges of water, nutrients, and organic matter occur in response to variations in discharge and bed topography and porosity. Dynamic gradients exist at all scales and vary temporally. Across all scales, the functional significance of the HZ relates to its activity and connection with the surface stream. The HZ is a relatively rich environment and almost all invertebrate groups have colonized this habitat. This fauna, so-called hyporheos, is composed of species typical from interstitial environment, and also of benthic epigean and phreatic species. The hyporheic microbiocenose consists in bacteria, archaea, protozoa and fungi. The HZ provides several ecosystem services, playing a pivotal role in mediating exchange processes, including both matter and energy, between surface and subterranean ecosystems, functioning as regulator of water flow, benthic invertebrates refuge and place of storage, source and transformation of organic matter. The hyporheic zone is one of the most threatened aquatic environments, being strongly influenced by human activities, and the least protected by legislation worldwide. Its maintenance and conservation is compelling in order to preserve the ecological interconnectivity among the three spatial dimensions of the aquatic environment. Although several researchers addressed the importance of the hyporheic zone early, and most contemporary stream ecosystem models explicitly include it, very little is known about the HZ of Neotropical regions. From a biological standpoint, hyporheos fauna in Neotropical regions are still largely underestimated. This review focuses on a brief presentation of the hyporheic zone and its functions and significance as an ecotone. We also highlighted the key aspects considering also the current status of research in Neotropical regions.
\end{abstract}

Keywords: Enterobacteriaceae, groundwater, meiofauna, macroinvertebrates, water exchange.

\section{A zona hiporréica e as suas funções: revisão e estado da arte da pesquisa na região neotropical}

\section{Resumo}

A zona hiporréica, como ecótono de ligação entre a superfície e as águas subterrâneas, é parte funcional seja dos ecossistemas fluviais seja das águas subterrâneas. As características hidrológicas, as características químicas, biológicas e metabólicas são específicas desta zona, não pertencendo verdadeiramente nem a superfície nem às águas subterrâneas. Trocas de água, nutrientes e matéria orgânica ocorrem em resposta a variações na descarga, topografia do álveo e porosidade. Gradientes dinâmicos existem em todas as escalas e variam temporalmente. Em todas as escalas, o significado funcional da zona hyporheic relaciona-se com a sua conexão e atividades com a água superficial. O HZ é um ambiente relativamente rico e quase todos os grupos de invertebrados colonizaram este habitat. Esta fauna, chamada hyporheos, é composta por espécies típicas do ambiente intersticial, e também de espécies bentônicas epígeas e freáticas. A microbiocenose consiste em bactérias, arqueobactérias, fungos e protozoários. $\mathrm{O}$ HZ fornece vários serviços para o ecossistema, desempenhando um papel fundamental na mediação de processos de troca, incluindo seja a matéria, seja a energia, entre os ecossistemas superfíciais e os subterrâneos, funcionando como regulador do fluxo de água, de refúgio para invertebrados bentônicos e local de armazenagem, fonte e transformação de matéria orgânica. A zona hyporheic é um dos ambientes aquáticos mais ameaçados, sendo fortemente influenciado pelas atividades humanas, e um dos menos protegidos pela legislação em todo o mundo. A sua manutenção e conservação é necessaria para preservar a interconectividade ecológica entre as três dimensões espaciais do ambiente aquático. Apesar de vários pesquisadores aborem a importância da zona hyporheic a tempo, e a maioria dos modelos de ecossistemas atualmente 
incluí-lo de forma explicita, muito pouco se sabe sobre o HZ das regiões neotropicais. Do ponto de vista biológico, a fauna hiporréica das regiões neotropicais é ainda largamente subestimada. Esta revisão visa apresentar de forma resumida a zona hiporréica, suas funções e importância como ecótono. Também visa destacar os aspectos principais considerando também o estado actual da investigação em regiões neotropicais.

Palavras-chave: Enterobacteriaceae, água subterranean, meiofauna, macroinvertebrados, troca de água.

\section{Introduction}

The water bodies are a broad integrated system that constitutes the "hydrologic landscape" of a given territory in complex networks of surface water, lakes, wetlands, rivers and groundwater. As a consequence, the analysis of the river ecosystem and the river basin management should consider four factors jointly: longitudinal, lateral, vertical and temporal (Boulton et al., 1998; Danielopol et al., 2004, 2008; European Commission, 2006; Ward, 1989).

Groundwater contribution has great importance in composition of surface waters (Hynes, 1983), and surface water depends on base flow (Boulton and Hancock, 2006), that is, the percentage of water in a channel that emerges from the underground. This relationship is due to two factors: i) the water passing through the substrate will, with time, be incorporated into the superficial system, ii) in many rivers, during the dry period, the base flow may constitute the majority of the water flowing in the channel. The interactions and range of hydrological and biogeochemical exchanges between surface water and groundwater are determined by the structure of the basin, reflecting the permeability of the aquifer, the local and regional geology, the water storage capacity of the river plain, the channel morphology, the topographical structure, the hydraulic conductivity of the riverbed sediments, the waterfront and the variations of recharge rate (Dahm et al., 1998; Wroblicky et al., 1998). These interactions influence both key stream ecosystem processes, such as primary productivity and nutrient cycling, and microbe and invertebrate communities' diversity and spawning from some fish (see Boulton et al., 2010 and references therein). The physical place where all those interactions occur, is the hyporheic zone (Orghidan, 2010) Although several researchers addressed the importance of the hyporheic zone early (e.g., Orghidan, 2010; Schwoerbel, 1967; Williams and Hynes, 1974), and most contemporary stream ecosystem models (e.g., Thorp et al., 2006) explicitly include it, very little is known about hyporheic zone of Neotropical regions.

This review focuses on a brief presentation of the hyporheic zone and its functions and significance as an ecotone. We highlighted the key aspects considering also the current status of research in Neotropical regions.

\subsection{Physical aspects}

The hyporheic zone (HZ) was formally nominated by Orghidan (2010). For this environment there is no single conceptual definition due to different terminologies, methodologies and dogma among biologists, hydrologists and geomorphologists (White, 1993). This zone is an active ecotone delimited superiorly by channel water and inferiorly by underground water (Bencala, 2000) being constituted by the interstitial spaces between the particles of the riverbed (Dahm and Valet, 1996).

Actually groundwater ecology is a multidisciplinary science that integrates hydrogeology and ecology. This multidisciplinary approach seeks to elucidate the function of groundwater ecosystems and their roles in maintaining subterranean and surface water quality.

The discipline of groundwater ecology started to develop during the end of the 19th century with natural history observations about organisms living in subsurface habitats (e.g., Schwoerbel, 1961); during the 1970s the incorporation of the concept of ecosystem structure and functioning into subsurface aquatic ecology represents the first major paradigm change (Danielopol and Griebler, 2008; Hancock et al., 2005).

In the decade of the 1990s, Gilbert et al. (1990) proposed the surface water/groundwater ecotone concept. In that concept the $\mathrm{HZ}$ is considered as a transition zone between two ecosystems that display characteristics of both. The ecotone approach led to a functional classification of hyporheic invertebrates into three broad groups based on their affinity to the groundwater habitat (Marmonier et al., 1993). Another significant advance was the study of the central role of hydrological exchange between groundwater and surface water in determining the chemistry and fauna of the hyporheic zone (e.g., Valett et al., 1993).

The "Hyporheic Corridor Concept" (HCC) was proposed by Stanford and Ward (1993), which emphasized the connection and interaction between $\mathrm{HZ}$ and hydrographic basin.

Boulton et al. (1998) explored the trends of interactions at different scale: sediment scale (sub-millimeter to meter), reach scale $(1-1,000 \mathrm{~m})$, catchment scale $(>1,000 \mathrm{~m})$.

More recently the idea of $\mathrm{HCC}$ was integrated in a broader context, integrating the stygoscape concept, introduced by Ward (1997), which designates the aquifers beneath alluvial flood plains equivalent to landscape, comprising the three saturated zones beneath and laterally of the alluvial, each with its chemical and biological properties interacting with the channel surface: hyporheic zones within the wetted channel, riparian zones furthest from the channel, and parafluvial zones between the hyporheic and riparian zones (Datry et al., 2008; Ward et al., 2002).

Thorp et al. (2006) proposed the Riverine Ecosystem Synthesis (RES) that considers the river as downstream arrays of large hydrogeomorphic patches formed by catchment geomorphology and flow characteristics, including the HZ. 
In the last two decades, the link between the disciplines of hydrogeology and groundwater ecology has become stronger. Ground- and surface- waters are considered interactive components of the same hydrologic system and cannot be treated singularly in the view of aquifer management and water quality remediation (Hancock et al., 2005; Humphreys, 2009).

The exact limits of the HZ is difficult to define, due to its variability in space and time (Williams, 1984). Its upper boundary, can be relatively easily delineated by the decline in light intensity and flow speed (Schwoerbel, 1964). As in deep groundwater habitats, HZ lacks of light. In well-illuminated surface water habitats four fundamental trophic levels may be recognized: primary producers, primary consumers, decomposers, and predators; in the subterranean habitats characterized by darkness only two (decomposers and predators or parasites) are significantly represented and in this sense, subterranean biodiversity, including hyporheic biodiversity, may be considered as strongly truncated basally (Gibert and Deharveng, 2002).

This interstitial environment receives dissolved organic substance through surface exchange, and, on the other hand, produces organic substances derived from animal, bacterial and fungal activity.

Thereby, the interstitial environment is one storage area of autochthonous and allochthonous organic materials and constitutes the area where bacteria most efficiently process the dissolved organic carbon and the concentration of nitrates, phosphates, silicates, organochlorines and heavy metals are higher in relation to the surface habitat (Bencala, 2005).

Under optimal conditions the $\mathrm{HZ}$ is interested by active hydric exchanges (surface water towards groundwater and viceversa) and can be extended vertically in meters and laterally in kilometers (Stanford et al., 1996; Ward, 1992).

In the HZ, in opposition to the superficial environment, the water flow is laminar and not unidirectional and the pressure gradient generated by the flow from the irregular river bed induces the water to move in and out of the riverbed (Hutchinson and Webster, 1998; Thibodeaux and Boyle, 1987) in a process known as hyporheic exchange (Harvey and Wagner, 2000).

From the flow point of view two riverbed zones can be delineated: the zone of non-Darcian flow towards the bed surface and the zone of Darcian flow deeper in the substrate (Bencala, 2000; Greig et al., 2005).

\subsection{Interstitial fauna}

From a biological standpoint, the $\mathrm{HZ}$ is a relatively rich environment and almost all invertebrate groups have colonized this habitat following multiple and successive colonization processes (Dole-Olivier, 2011; Stoch and Galassi, 2010). Subterranean populations are characterized by high proportion of endemic species and a large number of allopatric vicariant species often clusters in numerous metapopulations, results of geografical isolation or relicts of ancient faunas that may evolve into species with time (Porter, 2007).
Some groups are well represented below ground, whereas many others are absent. For example, crustaceans have been very successful with 12 orders present in the subterranean environment and the number of subterranean crustacean species may equal or exceed that of epigean ones in the same area; conversely, only a few of the huge number of freshwater aquatic insect families have subterranean representatives (Gibert and Deharveng, 2002).

This fauna, so-called hyporheos, is composed of species typical from interstitial environment, and also of benthic epigean and phreatic species (Gibert, 1991; Gibert et al., 1990; Kirchengast, 1984; Ruffo, 1961; Ward, 1992). Three categories of organisms can be distinguished based on habitat affinity: stygoxenes that have no affinities with the underground environment and that occur in it only accidentally; stygophiles that show some affinities but no specializations, actively exploring the resources and accomplishing part of their life cycle in it; stygobites that present morphological, physiological and ethological specializations to the underground habitats where they are bounded to complete their life cycle (Gibert et al., 1994).

The HZ is thought to serve multiple functions for lotic invertebrates. The benthic species use this area against competition or predation, nursery and refuge from the movement of the substrate or environmental variations due to seasonal flooding and drought (Dole-Oliver et al., 1997; James et al., 2008; Lencioni, 2004; Lencioni et al., 2008; Schwoerbel, 1967; Stubbington, 2012; Williams and Hynes, 1974). The role in the persistence of benthic assemblages in the after disturbances ('hyporheic refuge hypothesis', HRH) has been recently reviewed by DoleOlivier (2011) after its initial proposal in 1953. The active vertical migration of various insect orders when a stream water dries has been reported by Larimore et al. (1959) and successively reported by Boulton and Stanley (1995) in relation with desert streams. Among the insect larvae can be cited Ephemeroptera, Coleoptera and Diptera; however, adult insects like elmids and staphylinids are frequently observed too. The insects' larvae are generally confined to the upper layers, but some species penetrate deeper and can be an important component of the hyporheos (Fenoglio et al., 2006; Lencioni, 2004; Lencioni et al., 2008; Malard et al., 2002) like Chironomidae (Pinder, 1986; Reynolds Junior and Benke, 2006). Other groups perform vertical migrations: Crustacea, Annelida, Acari, Nematoda, Tricladida (Godbout and Hynes, 1982; Olsen and Townsend, 2003). Some authors (e.g. Boulton et al., 2004; Dole-Olivier, 2011; Dole-Olivier et al., 1997; Otermin et al., 2002; Palmer et al., 1992; Wood et al., 2010) argued that the recolonization of a water body after a catastrophic flood event is accomplished through vertical migration from $\mathrm{HZ}$.

At the catchment scale, the alternation of upwelling and downwelling sectors in the HZ may be mirrored by changes in the diversity of stygobiotic and non-stygobiotic hyporheic taxa, as observed in an Alpine stream by Di Lorenzo et al. (2013), thus supporting the hypothesis primarily formulated by Lafont et al. (1992) for oligochaetes, and subsequently 
developed by Lafont and Malard (2001) and Lafont and Vivier (2006), on the role of some meiofaunal species as active exchange describers, i.e. indicators of ground water/ surface water exchanges in the HZ.

Some fishes lay their eggs and spawn in gravel bed substrate. The HZ strongly influences the incubating embryos of gravel spawning fish species, particularly of those species that lay their eggs at depth within the gravel, such as salmonids. The typical salmonid burial depths range from 0.05 to $0.5 \mathrm{~m}$ (UK Environment Agency, 2009) and in the HZ the young develope (Heggenes et al., 2013). Kawanishi et al. (2013), studying the benthic fish Cobitis shikokuensis in an intermittent river, demonstrated that the HZ is a refuge habitat for this species in dry periods, highlighting the critical role of the hyporheic zone in population maintenance of some fishes.

\subsection{Microbs}

In the HZ, biogeochemical cycling, microbial ecology and the ecology of invertebrates community should not be considered as discrete compartments but rather as an interactive system. The hyporheic microbiocenose consists in bacteria, archaea, protozoa and fungi and can be found in plankton form, in interstitial areas like settled and movement form and in biofilms (Danielopol et al., 2004, 2008; Griebler and Lueders, 2009). The biofilm covers the inorganic granules and is probably the most important component of the interstitial environment (Bretschko and Leichtfried, 1988) since it is estimated that $10 \mathrm{~g}$ of sediment with a granule diameter of $0.1 \mathrm{~mm}$ can cover $1 \mathrm{~m}^{2}$ of surface (Malard et al., 2002). The few available studies concerning microbial communities in the HZ (Griebler and Lueders, 2009 and references herein), mainly focused on the ecology of bacteria rather than of the microbial diversity, showed that microbial community structures change among systems and show a seasonal pattern, as observed by Feris et al. (2003) and Hullar et al. (2006), conversely to what has been reported for aquifers for which seasonal dynamics have not been reported. Aaerobic bacteria, and enteric bacteria in the HZ showed significant differences between winter and summer or in upwelling and downwelling zone and temperature, inorganic nutrients, and occurrence of anoxic zones affected the distribution of enteric bacteria (UK Environment Agency, 2009)

For detailed revision and nutrient cycling fluxes and diagrams see: Gibert and Deharveng (2002), UK Environment Agency (2009).

\section{Functions}

The HZ plays a pivotal role in mediating exchange processes, including both matter and energy, between surface and subterranean ecosystems, functioning as regulator of water flow, benthic invertebrates refuge and place of storage, source and transformation of organic matter. The HZ can be considered a natural filter, able to mitigate and slow down chemical-physical variations that affect both surface and groundwater environments (Brunke and Gonser, 1997). Due to occurrence of temporary storage spaces and prolonged residence time of up- and down-welling water, nutrients and pollutants can be actively degraded and/or absorbed before they are spread in the water body (Boulton et al., 1998). Heterotrophic biofilm exerts a major influence in the biochemical transformation of contaminants such as pesticides, suggesting that the interface between running water and sediment plays a role in self-purification of stream reaches (Sánchez-Pérez et al., 2013).

\section{Human Impact}

From an ecological point of view, the HZ and its biological components are strongly influenced by human activities resulting in significant and persistent impacts (Hancock, 2002).

Due to the close proximity to the surface, hyporheic zones are particularly susceptible to contaminants from both the overlying stream and parafluvial flow. Potential contaminants include:

(1) sewage or fecal contamination with human or animal source. In developing countries sewage pollution is one of the biggest sources of pollution (Hoekstra and Mekonnen, 2012; Miguel, 1991). This situation is critical for human health due to the utilizations of deep or shallow wells for drinking water in some areas (Colvara et al., 2009; Fairbrother and Nadeau, 2006).

(2) pesticides, herbicides and fertilizers used for crops, trails, or roads, hazardous material introductions. As effect of the interaction between surface water and groundwater in watersheds where industries and intensive agricultural activities are performed, pesticides and heavy metals present in the field can reach the surface or the aquifers due to the movement of the water (Boulton et al., 1998; Di Lorenzo et al., 2012), far from the pollution source point, and may constitute a risk both to physical and chemical integrities of water resources (Boulton and Hancock, 2006). In Central and South America, chemicalintensive tropical agriculture is an important economic resource and still growing and the use of chemicals, in many countries, is not supported by an appropriate legislation, causing strong effect on freshwater fauna (Corbi et al., 2008; Egler et al., 2012; Aharonson, 1987; Nordstrom, 2002).

(3) extractive or deforestation activities. The extractive activity and deforestation of landscape and riparian areas determining long-term changes in hidrossedimentar dynamics and fauna (Pinto et al., 2006; Santos and Stevaux, 2010). Beside, it induces an increase in fine sediment causing clogging, filling the interstitial spaces (Richards and Bacon, 1994) and destroying groundwater-surface hydrological linkages. Descloux et al. (2013) observed that high amount of fine sediments within the HZ significantly decreased habitat quality for benthic and hyporheic invertebrates, thus limiting the production of streams 
and their capacity to recover after disturbance. River incision, climate changes and groundwater overuse induce increasing groundwater depletion and drought frequency in floodplains, affecting interstitial assemblages of the HZ (Dehedin et al., 2013);

(4) constructions of dams. Presence of dams change dynamic, composition and structure of epibenthic fauna (Callisto et al., 2005; Almeida et al., 2009) and can alter the water exchange (Fabian et al., 2011). Dams along small-order streams are known to alter the linkage between headwater and downstream reaches, potentially increasing at short distance hyporheic connectivity in the riparian zone (Duke et al., 2007). In particular, dams simplify alluvial system structure, reducing surface water peak flows and hyporheic flow and thus preventing refilling of alluvial aquifers (Poole and Berman, 2001).

\section{Maintenance and Restoration}

Today the importance of the $\mathrm{HZ}$ and groundwater on the dynamics and functioning of surface waters is recognized and there are already guidelines for their use and protection (Boulton et al., 1998; Danielopol et al., 2004, 2008; European Commission, 2006). Until now, however, research on watershed and freshwater management has segregated surface water and groundwater in different compartments and an integrated reading river-aquifer was only exceptionally attempted for sustainable management of water resources (Boulton et al., 1998).

The maintenance and conservation of interstitial habitats improve the ecological interconnectivity among the three spatial dimensions (Stanford et al., 1996), and preserve areas that contain allochthonous food-webs source. Consequently, the primary strategy for restoration of water bodies must provide for identification, stabilization and restoration of vertical linkages (Boulton, 2007).

The cryptic nature of the interstitial environment and its linkages, the lack of reference data and the lack of pragmatism in monitoring probably contributed for failure in many practical actions (Boulton, 2007; Boulton et al., 2010; Fernandez, 2005).

\section{Hyporheic Zone in Neotropical Region}

In the Neotropical Region the study of hyporheic fauna is scarce. The first study of interstitial fauna was accomplished by Fernández and Palacios (1989) using the collecting method Kararan-Chapuis (Chappuis, 1942). Some study about water exchanges, nutrients and chemistry was done in some countries (Cuajinicuilapa et al. (2012) in Mexico; Chestnut and McDowell (2000) in Puerto Rico; Fabian et al. (2011) in Honduras; Marchetti and CarrilloRivera, 2013 in Argentina; Medina et al., 2003 in Venezuela and Romero-González et al. (2001) in Venezuela; Smedt, (2007) and Smedt et al. (2006) in Chile). Otherwise only one work on hyporheic fauna was published from Argentina (Fernández and Palacios, 1989).

From a taxonomic group stand point only for two group were found list/or ecological papers: Hydrachnidia (Chelicerata) (Fernández, 2001, 2002; Fernández and Fossati-Gaschignard, 2011 for Argentina; Orghidan and Gruia, 1983 for Venezuela; Schwoerbel, 1986 for Chile); Oligochaeta (Annelida) (Botea, 1987 apud Rodríguez (2002) for Venezuela; Rodríguez (2002) for Cuba).

For freshwater Crustacea like Cladocera, Copepoda, Syncarida and Peracarida several monographs or lists are available (e.g. Boxshall and Defaye, 2008; Camacho and Valdecasas, 2008; Elmoor-Loureiro, 1997; Forró et al., 2008; Gaviria, 1989, 1994; Grosso, 1991; Grosso and Peralta, 2002; Löffler, 1981; Lopretto and Morrone, 1998; Mercado-Salas et al., 2012; Suárez-Morales et al., 1996; Noodt, 1965; Peralta and Grosso, 2009; Reid, 1988, 1998; Young, 1998; beside others), however exhaustive species descriptions and ecological remarks can found in the original descriptions.

Zooplankton group densities from two Venezuelan reservoirs, collected at different depths from oxygenated layers, were compared by Gonzalez et al. (2002). Copepods and rotifers were the dominant groups in both reservoirs, during the whole study period. In sediment samples, taken during a short-term study of the distribution of meiofauna from a coastal lagoon in Sinaloa (northwestern Mexico), Gomez (2002) collected several species of harpacticoids, some of which new to science.

In these works the habitus is indicated as interstitial, interstitial in river sand, groundwater, groundwater of river, groundwater in sandy beach of river, hyporheic and phreatic zone.

This heterogeneity of definition, jointly with the misidentification of habitats, due for example to hyporheic or phreatic species found in the up layers due to de upwelling, water can result in underestimation of underground biodiversity and errors in ecological studies (Fernández, 2004).

For Insecta Harrison (1966) and Hynes (1975), cited in Ward (1992), argued that the recolonization of a tropical water body after a catastrophic flood event can be principally due by ovodeposition by aerial adults differently from the temperate streams were the $\mathrm{HZ}$ may be a refuge for many species and therefore contains an important reservoir of organism to repopulate the surface. To our knowledge, the only work that includes hyporheic insects was accomplished by Fernández and Palacios (1989) using the collecting method Chamaran-Chapuis (Chappuis, 1942).

For the Vertebrata that can be found in the $\mathrm{HZ}$ of Neotropical regions, some fish species were described as psammophilic (sand-dwelling), microphagous carnivores with sit-and-wait strategy or active foraging tactics, as Pygidianops spp. and Typhlobelus spp. (Schaefer et al., 2005 from Venezuela), Imparfinis pristos (Mees and Cala, 1989 from Orinoco River in Colombia, apud Zuanon et al., 2006), Characidium cf. pteroides, Stauroglanis gouldingi, Gymnorhamphichthys rondoni, Mastiglanis asopos 
(Zuanon et al., 2006 from Orinoco Basin, Amazonia) and Phreatobius sp. (Bolivia).

For rivers and lakes waters, in general, there is a vast amount of information on the presence and survival of microbial quality indicators, but limited information relating to the $\mathrm{HZ}$.

In the Neotropical Region the studies of micro biota like bacteria in $\mathrm{HZ}$ is strategic. Some microbial communities in elevated concentrations, generally associated of human pollution, were found in superficial water sources in uninhabited rain forests (Rivera et al., 1988). Escherichia coli found upstream of known fecal sources showed a strong positive correlation with water temperature and nutrient concentrations (Carrillo et al., 1985; Jimenez et al., 1989; Mugnai et al., 2015; Rivera et al., 1988).

As in the mammalian host environment, nutrients in tropical ecosystems are maintained at high concentrations, and together with constant warm temperatures provide an ideal habitat for survival, growth, and proliferation of $E$. coli (Winfield and Groisman, 2003; Mugnai et al., 2015).

That characteristic can favorite other bacteria associated with human health like Salmonella spp. (Anderson et al., 2005; Fish and Pettibone, 1995; Winfield and Groisman, 2003; Mugnai et al., 2015). Consequently soil and sediment particles can function as microecological niches in which bacterial species can survive and replicate and result in risk for human health. However, these aspects are poorly investigated and represent a crucial point also in those regions worldwide where $\mathrm{HZ}$ was better studied (Marmonier et al., 2012; Mugnai et al., 2015).

\section{Acknowledgements}

We thank CAPES and FAPERJ for the financial support. Many thanks to Dr. Kury Adriano Museu Nacional/UFRJ for to allow the research in the Arachnology Laboratory, Gatti Mario Jorge Curator of Coleção Micológica de Trichocomaceae IOC/FIOCRUZ for the technical support. We are indebted with an anonymous reviewer who provided comments that improved the manuscript.

\section{References}

AHARONSON, N., 1987. Potential contamination of ground water by pesticides. Pure and Applied Chemistry, vol. 59, no. 10, p. 1419-1446. http://dx.doi.org/10.1351/pac198759101419.

ALMEIDA, EF., OLIVEIRA, RB., MUGNAI, R., NESSIMIAN, JL. and BAPTISTA, DF., 2009. Effects of small dams on the benthic community of streams in an Atlantic Forest Area of Southeastern Brazil. International Review of Hydrobiology, vol. 94, no. 2, p. 179-193. http://dx.doi.org/10.1002/iroh.200811113.

ANDERSON, KL., WHITLOCK, JE. and HARWOOD, VJ., 2005. Persistence and differential survival of fecal indicator bacteria in subtropical waters and sediments. Applied and Environmental Microbiology, vol. 71, no. 6, p. 3041-3048. http://dx.doi.org/10.1128/ AEM.71.6.3041-3048.2005. PMid:15933000.

BENCALA, KE., 2000. Hyporheic zone hydrological processes. Hydrological Processes, vol. 14, no. 15, p. 2797-2798. http://
dx.doi.org/10.1002/1099-1085(20001030)14:15<2797::AIDHYP402>3.0.CO;2-6.

BENCALA, KE., 2005. Hyporheic exchange flows. In ANDERSON, MG. and McDONNELL, JJ. (Eds.). Encyclopedia of hydrological sciences. New Jersey: John Wiley and Sons. p. 1733-1740. vol. 3.

BOULTON, A., HARVEY, M. and PROCTOR, H., 2004. Of spates and species: responses by interstitial water mites to simulated spates in a subtropical Australian river. Experimental \& Applied Acarology, vol. 34, no. 1-2, p. 149-169. http://dx.doi. org/10.1023/B:APPA.0000044445.30246.b2. PMid:15597606.

BOULTON, AJ. and HANCOCK, PJ., 2006. Rivers as groundwaterdependent ecosystems: a review of degrees of dependency, riverine processes and management implication. Australian Journal of Botany, vol. 54, no. 2, p. 133-144. http://dx.doi.org/10.1071/ BT05074.

BOULTON, AJ., 2007. Hyporheic rehabilitation in rivers: restoring vertical connectivity. Freshwater Biology, vol. 52, no. 4, p. 632650. http://dx.doi.org/10.1111/j.1365-2427.2006.01710.x.

BOULTON, AJ., DATRY, T., KASHARA, T., MUTZ, M. and STANFORD, JA., 2010. Ecology and management of the hyporheic zone: stream groundwater interactions of running waters and their floodplains. Journal of the North American Benthological Society, vol. 29, no. 1, p. 26-40. http://dx.doi.org/10.1899/08-017.1.

BOULTON, AJ., FINDLAY, S., MARMONIER, P. and VALETT, M., 1998. The functional significance of the Hyporheic zone in stream and river. Annual Review of Ecology and Systematics, vol. 29, no. 1, p. 59-81. http://dx.doi.org/10.1146/annurev.ecolsys.29.1.59.

BOULTON, AJ. and STANLEY, EH., 1995. Hyporheic processes during flooding and drying in a Sonoran Desert stream. II: Faunal dynamics. Archiv für Hydrobiologie, vol. 134, n. 1, p. 27-52.

BOXSHALL, GA. and DEFAYE, D., 2008. Global diversity of copepods (Crustacea: Copepoda) in freshwater. Hydrobiologia, vol. 595 , no. 1 , p. 195-207. http://dx.doi.org/10.1007/s10750007-9014-4.

BRETSCHKO, G. and LEICHTFRIED, M., 1988. Distribution of organic matter and fauna in a second order alpine gravel stream (Ritrodat-Lunz study area, Austria). Verhandlungen - Internationale Vereinigung für Theoretische und Angewandte Limnologie, vol. 23, p. 1333-1339.

BRUNKE, M. and GONSER, T., 1997. The ecological significance of exchange processes between rivers and groundwater. Freshwater Biology, vol. 37, no. 1, p. 1-33. http://dx.doi.org/10.1046/j.13652427.1997.00143.x.

CALLISTO, M., GOULART, M., BARBOSA, FAR. and ROCHA, O., 2005. Biodiversity assessment of benthic macroinvertebrates along a reservoir cascade in the lower São Francisco river (northeastern Brazil). Brazilian Journal of Biology $=$ Revista Brasileira de Biologia, vol. 65, no. 2, p. 229-240. http://dx.doi. org/10.1590/S1519-69842005000200006. PMid:16097725.

CAMACHO, AI. and VALDECASAS, AG., 2008. Global diversity of syncarids (Syncarida; Crustacea). Hydrobiologia, vol. 595, no. 1, p. 257-266. http://dx.doi.org/10.1007/s10750-007-9021-5.

CARRILLO, M., ESTRADA, E. and HAZEN, TC., 1985. Survival and enumeration of the fecal indicators Bifidobacterium adolescentis and Escherichia coli in a tropical rain forest watershed. Applied and Environmental Microbiology, vol. 50, no. 2, p. 468-476.

CHAPPUIS, PA., 1942. Eine neue Methode zur Untersuchung der Grundwasserfauna. Acta Scientiae Math Nat Kolozsvar, vol. 6, p. 3-7. 
CHESTNUT, TJ. and MCDOWELL, WH., 2000. C and N dynamics in the riparian and hyporheic zones of a tropical stream, Luquillo Mountains, Puerto Rico. Journal of the North American Benthological Society, vol. 19, no. 2, p. 199-214. http://dx.doi. org/10.2307/1468065.

COLVARA, JG., LIMA, AS. and SILVA, WP., 2009. Avaliação da contaminação de água subterrânea em poços artesianos no sul do Rio Grande do Sul. Brazilian Journal of Food Technology, vol. 2, p. 11-14.

CORBI, JJ., TRIVINHO-STRIXINO, S. and SANTOS, A., 2008. Environmental Evaluation of Metals in Sediments and Dragonflies Due to Sugar Cane Cultivation in Neotropical Streams. Water, Air, and Soil Pollution, vol. 195, no. 1-4, p. 325-333. http://dx.doi. org/10.1007/s11270-008-9749-1.

CUAJINICUILAPA, D., SANDOVAL, C. and CUAJINICUILAPA, D., 2012. Evidencias de interacción entre aguas superficiales y subterráneas. Revista Internacional de Estadística Y Geografia, vol. 3, no. 2, p. 116-129.

DAHM, CM., GRIMM, NB., MARMONIER, P., VALETT, HM. and VERVIER, P., 1998. Nutrient dinamics at the interface between surface waters and grounwater. Freshwater Biology, vol. 40, no. 3, p. 427-451. http://dx.doi.org/10.1046/j.1365-2427.1998.00367.x.

DAHM, CN. and VALET, HM., 1996. Hyporheic zones. In HAUER, FR. and LAMBERTI, GA. (Eds.). Methods in stream ecology. San Diego: Academic Press. p. 107-119.

DANIELOPOL, D. L., GRIEBLER, C., GUNATILAKA, A., HAHN, HJ., GIBERT, J., MERMILLOD-BLONDIN, F., MESSANA, G., NOTENBOOM, N. and SKET, B., 2008. Incorporation of groundwater ecology in environmental policy. In QUEVAUVILLER, P. (Ed.). Groundwater science and policy: an international overview. London: Royal Society of Chemistry. p. 671-689.

DANIELOPOL, DL. and GRIEBLER, C., 2008. Changing paradigms in groundwater ecology - from the 'living fossils' tradition to the 'new groundwater ecology'. International Review of Hydrobiology, vol. 93, no. 4-5, p. 565-577. http://dx.doi. org/10.1002/iroh.200711045.

DANIELOPOL, DL., GIBERT, J., GRIEBLER, C., GUNATILAKA, A., HAHN, HJ., MESSANA, G., NOTENBOOM, J. and SKET, B., 2004. Incorporating ecological perspectives in European groundwater management policy. Environmental Conservation, vol. 31, no. 3, p. 185-189. http://dx.doi.org/10.1017/S0376892904001444.

DATRY, T., SCARSBROOK, M., LARNED, S. and FENWICK, G., 2008. Lateral and longitudinal patterns within the stygoscape of an alluvial river corridor. Fundamental and Applied Limnology / Archiv für Hydrobiologie., vol. 171, no. 4, p. 335-347. http:// dx.doi.org/10.1127/1863-9135/2008/0171-0335.

DEHEDIN, A., DOLE-OLIVIER, M-J., PISCART, C., MIMOUN, D., BORNETTE, G. and MARMONIER, P., 2013. Long-term changes and drying modality affect interstitial assemblages of alluvial wetlands. Wetlands, vol. 33, no. 3, p. 537-550. http:// dx.doi.org/10.1007/s13157-013-0411-3.

DESCLOUX, S., DATRY, T. and MARMONIER, P., 2013. Benthic and hyporheic invertebrate assemblages along a gradient of increasing streambed colmation by fine sediment. Aquatic Sciences, vol. 65 , no. 8, p. $1532-1544$.

DI LORENZO, T., BRILLI, M., DEL TOSTO, D., GALASSI, DMP. and PETITTA, M., 2012. Nitrate sources and fate at the catchment scale of the Vibrata River and aquifer (central Italy): an analysis by integrating component approaches and nitrogen isotopes. Environmental Earth Sciences, vol. 67, no. 8, p. 2383 2398. http://dx.doi.org/10.1007/s12665-012-1685-0.

DI LORENZO, T., STOCH, F. and GALASSI, DMP., 2013. Incorporating the hyporheic zone within the river discontinuum: Longitudinal patterns of subsurface copepod assemblages in an Alpine stream. Limnologica, vol. 43, no. 4, p. 288-296. http:// dx.doi.org/10.1016/j.limno.2012.12.003.

DOLE-OLIVER, MJ., MARMONIER, P. and BEFFY, JL., 1997. Response of invertebrate to lotic disturbance: is the hyporheic zone a patchy refugium? Freshwater Biology, vol. 37, no. 2, p. 257-276. http://dx.doi.org/10.1046/j.1365-2427.1997.00140.x.

DOLE-OLIVIER, MJ., 2011. The hyporheic refuge hypothesis reconsidered: a review of hydrological aspects. Marine \& Freshwater Research, vol. 62, no. 11, p. 1281-1302. http://dx.doi. org/10.1071/MF11084.

DUKE, JR., WHITE, JD., ALLEN, PM. and MUTTIAH, RS., 2007. Riparian influence on hyporheic-zone formation downstream of a small dam in the Blackland Prairie region of Texas. Hydrological Processes, vol. 21, no. 2, p. 141-150.

EGLER, M., BUSS, DF., MOREIRA, JC. and BAPTISTA, DF., 2012. Influence of agricultural land-use and pesticides on benthic macroinvertebrate assemblages in an agricultural river basin in southeast Brazil. Brazilian Journal of Biology $=$ Revista Brasileira de Biologia, vol. 72, no. 3, p. 437-443. http://dx.doi.org/10.1590/ S1519-69842012000300004. PMid:22990812.

ELMOOR-LOUREIRO, MAL., 1997, Manual de identificação de cladóceros límnicos do Brasil. Brasília: Ed. Universa, 155 p.

European Commission, 2006. GroundWater protection directive. Directive 2006/118/EC of the european parliament and of the council of 12 December 2006. Official Journal of the European Community, vol. L372, 19-36. Available from: $<$ http://eur-lex. europa.eu/legal-content/EN/TXT/?uri=CELEX:32006L0118>. Access in: 05 Aug. 2012.

FABIAN, MW., ENDRENY, TA., BOTTACIN-BUSOLIN, A. and LAUTZ, LK., 2011. Seasonal variation in cascade-driven hyporheic exchange, northern Honduras. Hydrological Processes, vol. 25, no. 10, p. 1630-1646. http://dx.doi.org/10.1002/hyp.7924.

FAIRBROTHER, JM. and NADEAU, E., 2006. Escherichia coli: on-farm contamination of animals. Revue Scientifique et Technique (International Office of Epizootics), vol. 25, no. 2, p. 555-569. PMid:17094697.

FENOGLIO, S., BO, T. and BOSI, G., 2006. Deep interstitial habitat as a refuge for Agabus paludosus (fabricius) (Coleoptera: Dytiscidae) during summer droughts. The Coleopterists Bulletin, vol. 60, no. 1, p. 37-41. http://dx.doi.org/10.1649/842.1.

FERIS, KP., RAMSEY, PW., FRAZAR, C., RILLIG, MC., GANNON, JE. and HOLBEN, WE., 2003. Structure and seasonal dynamics of hyporheic zone microbial communities in free-stone rivers of the western United States. Microbial Ecology, vol. 46, no. 2, p. 200-215. PMid:14708745.

FERNÁNDEZ, HR. and FOSSATI-GASCHIGNARD, O., 2011. An initial classification of neotropical water mites (Acari: Hydrachnidia) based on habitat preferences. International Journal of Ecology, vol. 2011, p. 1-11. http://dx.doi.org/10.1155/2011/910540.

FERNÁNDEZ, HR. and PALACIOS, AN., 1989. La fauna intersticial hiporreica de dos rios de montana del noroeste de Argentina. Rivista di Idrobiologia, vol. 28, p. 231-246. 
FERNÁNDEZ, HR., 2001. Acaros hiporreicos de Argentina: nuevos datos sobre Neomamersinae Lundblad (Limnesiidae). Physis, vol. 58, no. 134-135, p. 21-28.

FERNÁNDEZ, HR., 2002. Interstitial water mites of Argentina: Omartacarus Cook (Omartacaridae) and Meramecia Cook (Limnesiidae) (Acari: Hydrachnidia). Zootaxa, vol. 73, p. 1-6.

FERNÁNDEZ, HR., 2004. Does wrong precedence assignment lead to underestimate in groundwater biodiversity? Oecologia Australis, vol. 14, p. 77-81.

FERNANDEZ, L., 2005. Risk of extinction of a rare catfish of Andean groundwater and its priority for conservation. Ambio, vol. 34, no. 3, p. 269-270. http://dx.doi.org/10.1579/0044-744734.3.269. PMid: 16042289 .

FISH, JT. and PETTIBONE, GW., 1995. Influence of freshwater sediment on the survival of Escherichia coli and Salmonella sp. as measured by three methods of enumeration. Letters in Applied Microbiology, vol. 20, no. 5, p. 277-281. http://dx.doi. org/10.1111/j.1472-765X.1995.tb00445.x. PMid:7766227.

FORRÓ, L., KOROVCHINSKY, NM., KOTOV, AA. and PETRUSEK, A., 2008. Global diversity of cladocerans (Cladocera; Crustacea) in freshwater. Hydrobiologia, vol. 595, no. 1, p. 177184. http://dx.doi.org/10.1007/s10750-007-9013-5.

GAVIRIA, S., 1989. The calanoid fauna (Crustacea, Copepoda) of the Cordillera Oriental of the Colombian Andes. Hydrobiologia, vol. 178, no. 2, p. 113-134. http://dx.doi.org/10.1007/BF00011663.

GAVIRIA, S., 1994. Los copepodos (Arthropoda, Crustacea) de vida libre de las aguas continentales de Colombia. Revista de la Academia Colombiana de Ciencies exatas, Fisicas y Naturales, vol. 19 , no. 73 , p. 361-385.

GIBERT, J. and DEHARVENG, L., 2002. Subterranean ecosystems: a truncated functional biodiversity. Bioscience, vol. 52, no. 6, p. 473-481. http://dx.doi.org/10.1641/0006-3568(2002)052[0473:SE ATFB]2.0.CO;2.

GIBERT, J., DOLE-OLIVIER, M-J., MARMONIER, P. and VERVIER, P., 1990. Surface waterground ecotones. In NAIMAN, RJ. and DECAMPS, H. (Eds.). The ecology ond management of aquatic-terrestrial ecotones. London: CRC Press. p. 199-226.

GIBERT, J., 1991. Groundwater system their boundaries: conceptual framework and prospects in groundwater ecology. Verhandlungen des Internationalen Verein Limnologie, vol. 24, p. 1605-1608.

GIBERT, J., DANIELOPOL, DL. and STANFORD, J., 1994. Groundwater ecology. New York: Oxford University Press. 382 p.

GIBERT, J., DOLE-OLIVIER, MJ., MARMONIER, P. and VERVIER, P., 1990. Surface waterground ecotones. In NAIMAN, RJ. and DECAMPS, H. (Eds.). The ecology and management of aquatic-terrestrial ecotones. London: CRC Press.

GODBOUT, L. and HYNES, HBN., 1982. The three dimensional distribution of the fauna in a single riffle in a stream in Ontario. Hydrobiologia, vol. 97, p. 87-96.

GOMEZ, S., 2002. Some additions to the Mexican fauna: the family paramesochridae (Copepoda : harpacticoida). Journal of Crustacean Biology, vol. 22, no. 3, p. 627-641.

GONZALEZ, EJ., ORTAZ, M., MATOS, ML., MENDOZA, J., PENAHERRERA, C. and CARILLO, V., 2002. Zooplankton from two neotropical reservoirs with different trophic states. Interciencia, vol. 27 , no. 10 , p. 551-558.
GREIG, SM., CARLING, PA., SEAR, DA. and WHITCOMBE, LJ., 2005. Refinement and application of a conductiometric standpipe technique for measuring interstitial flow velocity in salmonid spawning graves. Hydrobiologia, vol. 545, no. 1, p. 249-256. http://dx.doi.org/10.1007/s10750-005-3316-1

GRIEBLER, C. and LUEDERS, T., 2009. Microbial biodiversity in groundwater ecosystems. Freshwater Biology, vol. 54, no. 4, p. 649-677. http://dx.doi.org/10.1111/j.1365-2427.2008.02013.x.

GROSSO, LE. and PERALTA, M., 2002. Patagonaspides gen. n.; P. sandroruffoi sp. n. (Crustacea, Syncarida) first phreatobite species of a new anaspidacean family discovered in Patagonia with cladistic analysis of Stygocaridinea (Anaspidacea). Bollettino del Museo Civico di Storia Naturale di Verona Botanica Zoologia, vol. 26, p. 105-118.

GROSSO, LE., 1991. Protojaniridae (Isopoda Asellota) en aguas intersticiales continentals de Sudamerica. Cuyojanira riojana $\mathrm{n}$. gen. n. sp. Stygologia, vol. 7, no. 2, p. 119-125.

HANCOCK, PJ., 2002. Human impacts on the stream-groundwater exchange zone. Environmental Management, vol. 29, no. 6, p. 763781. http://dx.doi.org/10.1007/s00267-001-0064-5. PMid:11992170.

HANCOCK, PJ., BOULTON, AJ. and HUMPHREYS, WF., 2005. Aquifers and hyporheic zones: towards an ecological understanding of groundwater. Hydrogeology Journal, vol. 13, no. 1, p. 98-111. http://dx.doi.org/10.1007/s10040-004-0421-6.

HARRISON, AD., 1966. Recolonization of a Rhodesia stream after drought. Hydrobiologia, vol. 62, no. 3, p. 405-421.

HARVEY, JW. and WAGNER, BJ., 2000. Quantifying hydrologic interactions between streams and their subsurface hyporheic zones. In JONES, JB. and MULHOLLAND, PJ. (Eds.). Streams and ground waters. San Diego: Academic Press. p. 3-44.

HEGGENES, J., BREMSET, G. and BRABRAND, A., 2013. Visiting the hyporheic zone: young Atlantic salmon move through the substratum. Freshwater Biology, vol. 58, no. 8, p. 1720-1728. http://dx.doi.org/10.1111/fwb.12162.

HOEKSTRA, AY. and MEKONNEN, MM., 2012. The water footprint of humanity. Proceedings of the National Academy of Sciences of the United States of America, vol. 109, no. 9, p. 32323237. http://dx.doi.org/10.1073/pnas.1109936109. PMid:22331890.

HULLAR, MAJ., KAPLAN, LA. and STAHL, DA., 2006. Recurring seasonal dynamics of microbial communities in stream habitats. Applied and Environmental Microbiology, vol. 72, no. 1, p. 713-722. http://dx.doi.org/10.1128/AEM.72.1.713-722.2006. PMid:16391111.

HUMPHREYS, WF., 2009. Hydrogeology and groundwater ecology: does each inform the other? Hydrogeology Journal, vol. 17, no. 1, p. 5-21. http://dx.doi.org/10.1007/s10040-008-0349-3.

HUTCHINSON, PA. and WEBSTER, IT., 1998. Solute uptake in aquatic sediments due to current-obstacle interactions. Journal of Environmental Engineering, vol. 124, no. 5, p. 419-426. http:// dx.doi.org/10.1061/(ASCE)0733-9372(1998)124:5(419).

HYNES, HBN., 1983. Groundwater and stream ecology. Hydrobiologia, vol. 100, no. 1, p. 93-99. http://dx.doi.org/10.1007/ BF00027424.

HYNES, JD., 1975. Annual cycles of macroinvertebrates of a river in southern Ghana. Freshwater Biology, vol. 5, no. 1, p. 71-83. http://dx.doi.org/10.1111/j.1365-2427.1975.tb00122.x.

JAMES, ABW., DEWSON, ZS. and DEATH, R., 2008. Do stream macroinvertebrate use instream refugia in response to severe short- 
term flow reduction in New Zeland strem? Freshwater Biology, vol. 53, no. 7, p. 1316-1334. http://dx.doi.org/10.1111/j.13652427.2008.01969.x.

JIMÉNEZ, L., MUÑIZ, I., TORANZOS, GA. and HAZEN, TC., 1989. Survival and activity of Salmonella typhimurium and Escherichia coli in tropical freshwater. The Journal of Applied Bacteriology, vol. 67, no. 1, p. 61-69. http://dx.doi. org/10.1111/j.1365-2672.1989.tb04955.x. PMid:2674097.

KAWANISHI, R., INOUE, M., DOHI, R., FUJII, A. and MIYAKE, Y., 2013. The role of the hyporheic zone for a benthic fish in an intermitente river: a refuge, not a graveyard. Aquatic Sciences, vol. 75, no. 3, p. 425-431. http://dx.doi.org/10.1007/s00027-013-0289-4.

KIRCHENGAST, M., 1984. Faunistische Untersuchungen im hyporheischen Interstitial des Flusses Mur (Steiermark, Österreich). Internationale Revue der gesamten Hydrobiologie und Hydrographie, vol. 69, no. 5, p. 729-746. http://dx.doi. org/10.1002/iroh.19840690508.

LAFONT, M. and MALARD, F., 2001. Oligochaete communities in the hyporheicn zone of a glacial river, the Roseg River, Switzerland. Hydrobiologia, vol. 463, no. 1-3, p. 75-81. http:// dx.doi.org/10.1023/A:1013135120545.

LAFONT, M. and VIVIER, A., 2006. Oligochaete assemblages in the hyporheic zone and coarse surface sediments: their importance for understanding of ecological functioning of watercourses. Hydrobiologia, vol. 564, no. 1, p. 171-181. http:// dx.doi.org/10.1007/s10750-005-1717-9.

LAFONT, M., DURBEC, A. and ILLE, C., 1992. Oligochaete worms as biological describers of the interaction between surface and groundwaters: a first synthesis. Regulated Rivers: Research \& Management, vol. 7, no. 1, 65-73.

LARIMORE, RW., CHILDERS, WF. and HECKROTTE, C., 1959. Destruction and re-establishment of stream fish and invertebrates affected by drought. Transactions of the American Fisheries Society, vol. 88, no. 4, p. 261-285. http://dx.doi.org/10.1577/15488659(1959)88[261:DAROSF]2.0.CO;2.

LENCIONI, V., 2004. Survival strategies of freshwater insects in cold environments. Journal of Limnology, vol. 63, no. 1s, p. 45-55. http://dx.doi.org/10.4081/jlimnol.2004.s1.45.

LENCIONI, V., MARZIALI, L. and ROSSARO, B., 2008. Hyporheic chironomids in alpine streams. Boletim do Museu Municipal do Funchal (História Natural), vol. 13, p. 127-132.

LÖFFLER, H., 1981. Copepoda. In LÖFFLER, H. (Ed.). Aquatic biota of tropical South America Part 1: Copepoda. San Diego: San Diego State University. 323 p.

LOPRETTO, EC. and MORRONE, JJ., 1998. Anaspidacea, Bathynellacea (Crustacea, Syncarida), generalised tracks, and the biogeographical relationships of South America. Zoologica Scripta, vol. 27, no. 4, p. 311-318.

MALARD, F., DOLE-OLIVIER, MJ. and MATHIEU, J., 2002. Sampling manual for the assessment of regional groundwater biodiversity. Global Change, Climate and Biodiversity. Available from: $<$ http://pascalis.univ-lyon1.fr/results/samplingmanual. htmlhttp://pascalis.univ-lyon1.fr/results/samplingmanual.html>. Access in: 22 Apr.. 2011.

MARCHETTI, ZY. and CARRILLO-RIVERA, JJ., 2013. Tracing groundwater discharge in the floodplain of the parana river, argentina: implications for its biological communities. River Research and Applications., vol. 30, no. 2, p. 166-179. http:// dx.doi.org/10.1002/rra.2629.
MARMONIER, P., ARCHAMBAUD, G., BELAIDI, N., BOUGON, N., BREIL, P., CHAUVET, E., CLARET, C., CORNUT, J., DATRY, T., DOLE-OLIVIER, M-J., DUMONT, B., FLIPO, N., FOULQUIER, A., GÉRINO, M., GUILPART, A., JULIEN, F., MAAZOUZI, C., MARTIN, D., MERMILLOD-BLONDIN, F., MONTUELLE, B., NAMOUR, P., NAVEL, S., OMBREDANE, D., PELTE, T., PISCART, C., PUSCH, M., STROFFEK, S., ROBERTSON, A., SANCHEZ-PÉREZ, J-M., SAUVAGE, S., TALEB, A., WANTZEN, M. and VERVIER, P., 2012. The role of organisms in hyporheic processes: Gaps in current knowledge, needs for future research and applications. Annales de Limnologie, vol. 48, no. 3, p. 253-266. http://dx.doi.org/10.1051/limn/2012009.

MARMONIER, P., VERVIER, P., GIBER, J. and DOLEOLIVIER, MJ., 1993. Biodiversity in ground waters. Trends in Ecology \& Evolution, vol. 8, no. 11, p. 392-395. http://dx.doi. org/10.1016/0169-5347(93)90039-R. PMid:21236209.

MEDINA, HL., MARÍN, JC., GUTIÉRREZ, E. and MORALES, J., 2003. Nitrogen mobility at the sediment-water interface of Lake Maracaibo, Venezuela. Water, Air, and Soil Pollution, vol. 145, no. 1-4, p. 341-357. http://dx.doi.org/10.1023/A:1023632702886.

MERCADO-SALAS, NF., POZO, C., MORRONE, JJ. and SUÁREZ-MORALES, E., 2012. Distribution patterns of the american species of the freshwater genus Eucyclops (Copepoda: Cyclopoida). Journal of Crustacean Biology, vol. 32, no. 3, p. 457-464. http://dx.doi.org/10.1163/193724012X626502.

MIGUEL, A., 1991. Environmental pollution research in South America. Environmental Science \& Technology, vol. 25, no. 4, p. 590-594. http://dx.doi.org/10.1021/es00016a603.

MUGNAI, R., SATTAMINI, A., SANTOS, JAA. and REGUAMANGIA, AH., 2015. A survey of Escherichia coli and Salmonella in the Hyporheic Zone of a subtropical stream: their bacteriological, physicochemical and environmental relationships. PloS one, vol. 10, n. 6, e0129382.

NOODT, W., 1965. Crustacea subterranea aus Argentinien: Mit 215 abbildungen. Studies on Neotropical Fauna and Environment, vol. 4, no. 2, p. 84-129.

NORDSTROM, DK., 2002. Public health. Worldwide occurrences of arsenic in ground water. Science, vol. 296, no. 5576, p. 21432145. http://dx.doi.org/10.1126/science.1072375. PMid:12077387.

OLSEN, DA. and TOWNSEND, CR., 2003. Hyporheic community composition in a gravel-bed stream: influence of vertical hydrological exchange, sediment structure and physicochemistry. Freshwater Biology, vol. 48, no. 8, p. 1363-1378. http://dx.doi. org/10.1046/j.1365-2427.2003.01097.x.

ORGHIDAN, T. and GRUIA, M., 1983. Quelques données sur la faune hyporhéique des hydracariens de Cuba. Memoires de Biospeologie, vol. 10, p. 339

ORGHIDAN, T., 2010. Ein neuer lebensraum des unterirdischen wasser: der hyporheische biotop. Fundamental and Applied Limnology / Archiv für Hydrobiologie, vol. 55, p. 392-414. http:// dx.doi.org/10.1127/1863-9135/2010/0176-0291. First published in German in 1959.

OTERMIN, A., BASAGUREN, A. and POZO, J., 2002. Recolonization by the macroinvertebrate community after a drought period in a first-order stream (Agüera Basin, Northern Spain). Limnetica, vol. 21, no. 1-2, p. 117-128.

PALMER, MA., BELY, AE. and BERG, KE., 1992. Response of invertebrates to lotic disturbance: a test of the hyporheic refuge 
hypothesis. Oecologia, vol. 89, no. 2, p. 182-194. http://dx.doi. org/10.1007/BF00317217.

PERALTA, M. and GROSSO, LE., 2009. Crustacea syncarida, amphipoda y decapoda. In DOMÍNGUEZ, E. and FERNÁNDEZ, HR. (Eds.). Macroinvertebrados bentónicos de sudamérica. Tucumán: Fundación Miguel Lillo. p. 469-495.

PINDER, LCV., 1986. Biology of freshwater Chironomidae. Annual Review of Entomology, vol. 31, p. 1-23.

PINTO, BCT., ARAUJO, FG. and HUGHES, RM., 2006. Effects of landscape and riparian condition on a fish index of biotic integrity in a large southeastern Brazil river. Hydrobiologia, vol. 556, p. 69-83.

POOLE, GC. and BERMAN, CH., 2001. An ecological perspective on in-stream temperature: Natural heat dynamics and mechanisms of human-caused thermal degradation. Environmental Management, vol. 27 , n. 6 , p. $787-802$

PORTER, ML., 2007. Subterranean biogeography: what have we learned from molecular techniques? Journal of Caves and Karst Studies, vol. 69, no. 1, p. 179-186.

REID, JW., 1988. Cyclopoid and Harpacticoid Copepods (Crustacea) from Mexico, Guatemala, and Colombia. Transactions of the American Microscopical Society, vol. 107, no. 2, p. 190-202. http://dx.doi.org/10.2307/3226461

REID, JW., 1998. Maxillopoda - Copepoda. Harpacticoida. In YOUNG, PS. (Ed.). Catalogue of Crustacea of Brazil. Rio de Janeiro: Museu Nacional. p. 75-127. Série Livros, no. 6.

REYNOLDS JUNIOR, SK. and BENKE, AC., 2006. Chironomid emergence and relative emergent biomass from two Alabama Streams. Southeastern Naturalist (Steuben, ME), vol. 5, no. 1, p. 165-174. http://dx.doi.org/10.1656/1528-7092(2006)5[165:CE AREB]2.0.CO;2.

RICHARDS, C. and BACON, KL., 1994. Influence of fine sediment on macroinvertebrate colonization of surface and hyporheic stream substrates. The Great Basin Naturalist, vol. 54, p. 106-113.

RIVERA, SC., HAZEN, TC. and TORANZOS, GA., 1988. Isolation of fecal coliforms from pristine sites in a tropical rain forest. Applied and Environmental Microbiology, vol. 54, no. 2, p. 513-517. PMid:3281583.

RODRÍGUEZ, P., 2002. Benthic and subterranean aquatic oligochaete fauna (Annelida, Oligochaeta) from Coiba Island (Panamá) and Cuba. Graellsia, vol. 58, no. 2, p. 3-19. http:// dx.doi.org/10.3989/graellsia.2002.v58.i2.275.

ROMERO-GONZÁLEZ, ME., ZAMBRANO, E., MESA, J. and MEDINA, HL., 2001. Fractional phosphate composition in sediments from a tropical river (Catatumbo River, Venezuela). Hydrobiologia, vol. 450, no. 1-3, p. 47-55. http://dx.doi. org/10.1023/A:1017535216608.

RUFFO, S., 1961. Problemi relativi allo studio della fauna interstiziale iporreica. Bollettino di Zoologia, vol. 28, no. 2, p. 273-319. http://dx.doi.org/10.1080/11250006109438340.

SÁNCHEZ-PÉREZ, JM., MONTUELLE, B., MOUCHET, F., GAUTHIER, L., JULIEN, F., SAUVAGE, S., TEISSIER, S., DEDIEU, K., DESTRIEUX, D., VERVIER, P. and GERINO, M., 2013. Role of the hyporheic heterotrophic biofilm on transformation and toxicity of pesticides. Annales de Limnologie, vol. 49, no. 2, p. 87-95. http://dx.doi.org/10.1051/limn/2013041.
SANTOS, DN. and STEVAUX, JC., 2010. Alterações de longa duração na dinâmica hidrossedimentar por extração de areia no alto curso do Rio Paraná na região de Porto Rico, PR. Geociências (São Paulo), vol. 29, no. 4, p. 603-612.

SCHWOERBEL, J., 1961. Über die Lebensbedingungen und die Besiedlung des hyporheischen Lebensraumes. Archiv für Hydrobiologie Supplement, vol. 25, p. 182-214.

SCHWOERBEL, J. 1964. Die Bedeutung des Hyporheals für die benthische Lebensgemeinschaft der Fließgewässer. Internationale Vereinigung für Theoretische und Angewandte Limnologie, vol. 15 , p. $215-226$

SCHWOERBEL, J., 1967. Das hyporheische Interstitial als Grenzbiotop zwischen oberirdischem und subterranem Ökosystem und seine Bedeutung für die Primär-Evolution von Kleinsthöhlenbewohnern. Archiv für Hydrobiologie, vol. 33, no. 6, p. 1-62.

SCHWOERBEL, J., 1986. Rheophile Wassermilben (Acari) aus Chile. I. Archiv für Hydrobiologie, vol. 106, p. 71-78.

SMEDT, F., 2007. Analytical solution and analysis of solute transport in rivers affected by diffusive transfer in the hyporheic zone. Journal of Hydrology (Amsterdam), vol. 339, no. 1-2, p. 29-38. http://dx.doi.org/10.1016/j.jhydrol.2007.02.002.

SMEDT, F., BREVIS, W. and DEBELS, P., 2006. Analytical solution for solute transport resulting from instantaneous injection in streams with transient storage. Journal of Hydrology (Amsterdam), vol. 330 , no. $3-4$, p. $759-760$.

STANFORD, JA., WARD, JV., LISS, WJ., FRISSELL, CA., WILLIAMS, RN., LICHATOWICH, JA. and COUTANT, CC., 1996. A general protocol for restoration of regulated rivers. Regulated Rivers: Research \& Management, vol. 12, no. 4-5,p. 391-413. http:// dx.doi.org/10.1002/(SICI)1099-1646(199607)12:4/5<391::AIDRRR436>3.0.CO;2-4.

STANFORD, JA. and WARD, JV., 1993. An ecosystem perspective of aluvial rivers: connectivity and the hyporheic corridor. Journal of North American Benthological Society, vol. 12, no. 1, p. 48-60.

STOCH, F. and GALASSI, DM., 2010. Stygobiotic crustacean species richness: a question of number, a matter of scale. Hydrobiologia, vol. 653, no. 1, p. 217-234. http://dx.doi.org/10.1007/ s10750-010-0356-y.

STUBBINGTON, R., 2012. The hyporheic zone as an invertebrate refuge: a review of variability in space, time, taxa and behaviour. Marine \& Freshwater Research, vol. 63, no. 4, p. 293-311. http:// dx.doi.org/10.1071/MF11196.

SUÁREZ-MORALES, E., REID, JW., ILIFFE, T. and FIERS, F., 1996. Catalogo de los Copepodos (Crustacea) continentales de la peninsula de Yucatan, Mexico. Mexico, DF: Conabio/Ecosur. $296 \mathrm{P}$.

THIBODEAUX, LJ. and BOYLE, JD., 1987. Bedform-generated convective transport in bottom sediment. Nature, vol. 325, no. 6102, p. 341-343. http://dx.doi.org/10.1038/325341a0.

THORP, JH., THOMS, MC. and DELONG, MD., 2006. The riverine ecosystem synthesis: biocomplexity in river networks across space and time. River Research and Applications, vol. 22, no. 2, p. 123-147. http://dx.doi.org/10.1002/rra.901.

UK Environment Agency, 2009. The hyporheic handbook: a handbook on the groundwater-surface water interface and hyporheic zone for environment managers. Bristol: UK Environmental Agency. $262 \mathrm{p}$.

VALETT, HM., HAKENKAMP, CC. and BOULTON, AJ., 1993. Perspectives on the hyporheic zone: integrating hydrology and 
biology. Journal of the North American Benthological Society, vol. 12, no. 1, p. 40-43. http://dx.doi.org/10.2307/1467683.

WARD, JV. 1997. An expansive perspective of riverine landscapes: pattern and process across scales. GAIA-Ecological Perspectives for Science and Society, vol. 6, no. 1, p. 52-60.

WARD, JV., 1989. The four-dimensional nature of lotic ecosystems. Journal of the North American Benthological Society, vol. 8, no. 1, p. 2-8. http://dx.doi.org/10.2307/1467397.

WARD, JV., 1992. Aquatic insect ecology. 1 Biology and habitat. Singapore: John Wiley \& Sons. 438 p.

WARD, JV., MALARD, F. and TOCKNER, K., 2002. Landscape ecology: a framework for integrating pattern and process in river corridors. Landscape Ecology, vol. 17, no. 1, supplement, p. 3545. http://dx.doi.org/10.1023/A:1015277626224.

WHITE, DS., 1993. Perspective on defining and delineatinghyporheic zones. Journal of the North American Benthological Society, vol. 12, no. 1, p. 61-69. http://dx.doi.org/10.2307/1467686.

WILLIAMS, DD., 1984. The hyporheic zone as a habitat for aquatic insects and associated arthropods. In RESH, VH. and ROSENBURG, DR. (Eds.). The ecology of aquatic insects. New York: Praeger Publishers. p. 430-455.

WILLIAMS, DD. and HYNES, HBN., 1974. The occurrence of benthos deep in the substratum of a stream. Freshwater Biology, vol.
4, no. 3, p. 233-256. http://dx.doi.org/10.1111/j.1365-2427.1974. tb00094.x.

WINFIELD, MD. and GROISMAN, EA., 2003. Role of nonhost environments in the lifestyles of Salmonella and Escherichia coli. Applied and Environmental Microbiology, vol. 69, no. 7, p. 3687-3694. http://dx.doi.org/10.1128/AEM.69.7.3687-3694.2003. PMid:12839733.

WOOD, PJ., BOULTON, AJ., LITTLE, S. and STUBBINGTON, R., 2010. Is the hyporheic zone a refugium for aquatic macroinvertebrates during severe low flow conditions? Fundamental and Applied Limnology / Archiv für Hydrobiologie, vol. 176, no. 4, p. 377-390. http://dx.doi.org/10.1127/1863-9135/2010/0176-0377.

WROBLICKY, GJ., CAMPANA, ME., VALETT, HM. and DQAHM, CM., 1998. Seasonal variation in surface: subsurface water exchange and lateral hyporheic area of two stream-aquifer system. Water Resources Research, vol. 34, p. 317-328.

YOUNG, PS., 1998. Catalogue of Crustacea of Brazil. Rio de Janeiro: Museu Nacional. 717 p. Série Livros.

ZUANON, J., BOCKMANN, FA. and SAZIMA, I., 2006. A remarkable sand-dwelling fish assemblage from central Amazonia, with comments on the evolution of psammophily in South American freshwater fishes. Neotropical Ichthyology, vol. 4, no. 1, p. 107-118. 